\title{
AIR POLLUTION IN ANCONA HARBOUR, ITALY
}

\author{
LORENZO FILENI ${ }^{1}$, ENRICO MANCINELLI ${ }^{1}$, MAURO MORICHETTI ${ }^{1}$, GIORGIO PASSERINI ${ }^{1}$, \\ UMBERTO RIZZA $^{2} \&$ SIMONE VIRGILI $^{1}$ \\ ${ }^{1}$ Department of Industrial Engineering and Mathematical Science, Marche Polytechnic University, Italy \\ ${ }^{2}$ Institute of Atmospheric Sciences and Climate, National Research Council of Italy, Italy
}

\begin{abstract}
Ports have always been communication and trade crossroads and have historically promoted the development of local economies. However, being hubs of activities, they are also major sources of noise and air pollution mainly due to ships, but also to vehicles, appliances, offices, etc. The port of Ancona, like many other Italian ports, is very close to the urban area, therefore it strongly influences the air quality of the city so that prolonged exposure to air pollutants generated by the port may cause adverse health effects on a big part of local population. Reducing air pollution without penalizing the local economy is one of the main objectives of the local authorities. The aim of the present study is to evaluate the contribution of different port emission sources, such as "Roll-on/roll-off Passengers" (Ro-pax) ships and fishing vessels, to Ancona air pollution. Between all, the levels of carbon monoxide (CO), volatile organic compounds (VOCs), nitrogen oxides ( $\mathrm{NOx}$ ), sulphur oxides ( $\mathrm{SO}$ ), and particulate matter (PM) have been evaluated. The study pointed out that most of the emissions in Ancona harbour are due to "Roll-on/roll-off" (Ro-ro) and Ro-pax maritime activities. Thus we focused on Ro-ro/Ro-pax ships' different emission scenarios based on different sulphur percentages in ship fuel, annual ships calls, manoeuvring/hotelling schedule, and ship characteristics, such as engine power. SOx denoted a strong dependency not only on the percentage of sulphur but also upon the manoeuvring/hotelling time while all other pollutant emissions mostly depend on timing and ship features. Therefore, it was found necessary to know such data exactly to estimate the emissions so to formulate new scenarios in order to choose the best strategies to reduce air pollution.
\end{abstract}

Keywords: ship emissions, manoeuvring, hotelling, AERMOD.

\section{INTRODUCTION}

Because of the proximity of ports to urban areas, shipping and port activities may strongly contribute to urban air pollution. Donateo et al. [1] estimated the average relative contribution of ship traffic to the measured $\mathrm{PM}_{2.5}$ concentrations in the port city of Brindisi. They valued that ship traffic accounted for $7.4 \%$ and ship traffic plus port related activities (loading/unloading of ships and hoteling) accounted for 9.3\%. In the Venice port area, the contribution of ship traffic emission to atmospheric aerosol $\left(\mathrm{PM}_{10}\right.$ and $\left.\mathrm{PM}_{2.5}\right)$ was estimated by Contini et al. in a range from $1 \%$ up to $8 \%$ [2].

More in general, based on the environmental data provided by 90 European ports, air quality ranks first among the environmental issues despite the different size and geographical location of ports [3]. The proximity of ports to residential areas results in prolonged exposure to air pollutants generated by port activities causing adverse health effects on local population. Bauleo et al. [4] reported long term effects on mortality for the residents in the proximity $(<500 \mathrm{~m})$ of the Civitavecchia port. They estimated an adjusted health risk of mortality equal to 1.11 for all cancers and equal to 1.31 for mortality from lung cancer.

Different manoeuvring and hoteling schedules affect the emissions of air pollutants due to ships in a port. The power requested by hoteling activities is generally supplied by the auxiliary engine but the main engine is also involved. This results in different engine-power requests and related fuel consumptions. In Naples port [5], about $98 \%$ of nitrogen oxides $\left(\mathrm{NO}_{\mathrm{X}}\right)$ and sulphur oxides $\left(\mathrm{SO}_{\mathrm{X}}\right)$ emissions due to cruise ships were ascribed to hoteling activities and about $2 \%$ to manoeuvring (navigation in port and approaching to docks). In 
Ancona port, in 2011, the $\mathrm{PM}_{10}$ emissions from ships were 28,350 kg, with the hoteling phase contributing to total particulate emissions for more than $76 \%$ [6].

The European Directive 2005/33/EC [7] introduced more stringent marine-fuel sulphur limits for ships at berth or cruising inside European coastal waters. This reduced the contribution of ship cruising, manoeuvring and hoteling to atmospheric pollutants such as $\mathrm{SO}_{2}[8]$ and primary particulate matter $\left(\mathrm{PM}_{10}\right.$, and $\left.\mathrm{PM}_{2.5}\right)$ [9].

The aim of the present study is to evaluate the present contribution of different port emission sources to Ancona air pollution. Between all, we studied "Roll-on/roll-off" (Ro-ro) and "Roll-on/roll-off Passengers" (Ro-pax) ships and fishing vessels.

The port of Ancona is among the most important ports in the Adriatic Sea with a large traffic of passengers. EU's ports strategy includes Ancona port as hub of the ScandinavianMediterranean corridor under the Trans-European Transport Network. Yet, the port of Ancona is very close to the urban area, likely influencing the air quality of densely populated areas of the city. Therefore, it is important to assess the contribution of different sources of air pollutants to local air quality to implement the most effective environmental policies and control strategies.

The levels of carbon monoxide (CO), volatile organic compounds (VOCs), $\mathrm{NO}_{\mathrm{X}}, \mathrm{SO}_{\mathrm{X}}$, and particulate matter (PM) were evaluated. Next, we focused on Ro-ro/Ro-pax ships' different emission scenarios based on different annual ships calls, manoeuvring/hoteling schedules, and ship characteristics such as engine power. Finally, the impacts of the different port emission sources on the $\mathrm{PM}_{10}$ levels in Ancona have been evaluated by using the Gaussian plume model AERMOD.

\section{ROLL-ON/ROLL-OFF SHIPS AND ROLL-ON/ROLL-OFF PASSENGERS SHIPS}

The main business of the Ancona port is represented by passenger and freight traffic towards the eastern coast of Adriatic Sea (especially Greece, but also Croatia and Albania). We propose three different scenarios for estimating emissions. Our approaches use fuel consumption as an indicator of primary activity and hypothesize average emission characteristics of ships to calculate emissions estimates. Between all, we collected data about the number of calls, ship characteristics, hotelling/manoeuvring intervals, and engine main features. When the official data were unknown, the auxiliary engine characteristics were derived from that of the main engine hypothesizing a power ratio of $1 / 10$. When available (e.g. for the cruise ships) the real value was introduced. The specific fuel consumption was assumed equal to 240.2 ( $\mathrm{g}$ fuel $/ \mathrm{kWh}$ ) as an average value for all ships, defined by the various engine and/or fuel type combinations.

For this study, we considered the use of the main motors during the manoeuvring and the power of the auxiliary engines during hotelling. The emission factors correspond to the Tier 1 approach of EMEP/EEA Air Pollutant Emission Inventory Guidebook [10]. $\mathrm{SO}_{\mathrm{X}}$ emissions are directly linked to sulphur content of fuel and, obviously, to the fuel consumption. Based on present regulations and praxis, in agreement with other studies [11], [12], we postulated the use of $1.5 \%$ sulphur fuel during manoeuvring and $0.1 \%$ sulphur fuel in the hotelling phase. The International Maritime Organisation (IMO) regulations expect to reduce the percentage of sulphur to $0.5 \%$ outside an Emission Control Area (ECA) and $0.1 \%$ inside the ECA from 1st of January 2020 [13]. Most ships, which operate both outside and inside these ECA, will therefore operate on different fuel oils in order to comply with the relevant limits. 
Table 1: Engine power and average fuel consumption for studied ships.

\begin{tabular}{|l|c|c|}
\hline Name of ship & Auxiliary engine power $(\mathrm{kW})$ & Main engine power $(\mathrm{kW})$ \\
\hline SUPERFAST XI & 4,800 & 48,000 \\
\hline AF MARINA & 1,152 & 11,520 \\
\hline MARKO POLO & $1,501.4$ & 15,014 \\
\hline CRUISE OLYMPIA & 29,100 & 55,440 \\
\hline CRUISE EUROPA & 29,100 & 55,440 \\
\hline OLYMPIC CHAMPION & 4,500 & 50,400 \\
\hline AURELIA & 1,412 & 14,120 \\
\hline ZADAR & 700 & 7,000 \\
\hline BRIDGE & $3,760.3$ & $37,603.7$ \\
\hline HELLENIC SPIRIT & 5,040 & 50,400 \\
\hline
\end{tabular}

\subsection{First emission scenario}

This scenario was based upon general statistical data for all the maritime activities of ferries. The main engines were considered at maximum power throughout the manoeuvring phases and the auxiliary engines were considered at maximum power throughout the hotelling phase. The hotelling phase was fixed at $10 \mathrm{~h}$ and the manoeuvring phase at $0.8 \mathrm{~h}$ as suggested by Entec [14]. Based on these assumptions, fuel consumption was calculated for both phases, considering the calendar year as the reference period.

Tables 2 and 3 show the results obtained by applying the emission factors of the Tier 1 approach. Different marine fuels used in the two phases and different percentages of sulphur content were considered for $\mathrm{SO}_{\mathrm{X}}$ calculation, as above explained. The precautionary estimate of some parameters (between all engine power and timing) and the Tier 1 approach lead to high values of $\mathrm{NO}_{\mathrm{X}}$ and $\mathrm{SO}_{\mathrm{X}}$ emissions.

Table 2: First scenario: ship calls and fuel consumption during hotelling (10 h/call) and manoeuvring $(0.8 \mathrm{~h} /$ call $)$.

\begin{tabular}{|l|c|c|c|}
\hline Name of ship & Ship calls & $\begin{array}{c}\text { Fuel consumption } \\
\text { (Mg/year) hotelling }\end{array}$ & $\begin{array}{c}\text { Fuel consumption } \\
\text { (Mg/year) manoeuvring }\end{array}$ \\
\hline SUPERFAST XI & 123 & $1,418.1$ & $1,134.5$ \\
\hline AF MARINA & 157 & 434.4 & 347.5 \\
\hline MARKO POLO & 137 & 494.1 & 395.3 \\
\hline CRUISE OLYMPIA & 183 & $12,791.4$ & $1,949.6$ \\
\hline CRUISE EUROPA & 183 & $12,791.4$ & $1,949.6$ \\
\hline OLYMPIC CHAMPION & 114 & $1,232.2$ & $1,104.1$ \\
\hline AURELIA & 104 & 352.73 & 282.2 \\
\hline ZADAR & 62 & 104.25 & 83.4 \\
\hline BRIDGE & 54 & 487.75 & 390.2 \\
\hline HELLENIC SPIRIT & 114 & $1,380.09$ & $1,104.1$ \\
\hline
\end{tabular}

Table 3: First scenario: Total emissions due to Ro-Ro/Ro-Pax ferries in Ancona harbour.

\begin{tabular}{|c|c|c|c|c|}
\hline $\begin{array}{c}\mathrm{NO}_{\mathrm{x}} \\
(\mathrm{Mg} / \text { year })\end{array}$ & $\begin{array}{c}\mathrm{CO} \\
(\mathrm{Mg} / \text { year })\end{array}$ & $\begin{array}{c}\mathrm{COVNM} \\
(\mathrm{Mg} / \text { year })\end{array}$ & $\begin{array}{c}\mathrm{SO}_{\mathrm{x}} \\
(\mathrm{Mg} / \text { year })\end{array}$ & $\begin{array}{c}\mathrm{PM}_{10} \\
(\mathrm{Mg} / \text { year })\end{array}$ \\
\hline 2744.4 & 258.7 & 97.9 & 348.2 & 52.4 \\
\hline
\end{tabular}




\subsection{Second scenario}

As in the first scenario, main engines and auxiliary engines were considered at maximum power throughout the manoeuvring and hotelling phase respectively. The manoeuvring phase was confirmed at $0.8 \mathrm{~h}$ while the hotelling timing and the ships calls represent the true scenario of Ancona harbour in 2016. This time, hotelling schedule is characteristic for each ship. Following these considerations, fuel consumptions were recalculated in both phases.

In this scenario there is a drastic reduction (more than 50\%) for all pollutants but for $\mathrm{SO}_{\mathrm{X}}$ that is much more influenced by the manoeuvring phase and by the marine fuel used.

Table 4: Second scenario: ship calls and fuel consumption during hotelling and manoeuvring $(0.8 \mathrm{~h} /$ call $)$.

\begin{tabular}{|l|c|c|c|c|}
\hline Name of ship & Ship calls & $\begin{array}{c}\text { Hotelling } \\
(\mathrm{h})\end{array}$ & $\begin{array}{c}\text { Fuel consumption } \\
\text { (Mg/year) } \\
\text { hotelling }\end{array}$ & $\begin{array}{c}\text { Fuel consumption } \\
\text { (Mg/year) } \\
\text { manoeuvring }\end{array}$ \\
\hline SUPERFAST XI & 316 & 7.0 & $2,550.3$ & $2,914.7$ \\
\hline AF MARINA & 60 & 5.0 & 83.0 & 132.8 \\
\hline MARKO POLO & 144 & 26.0 & $1,350.2$ & 415.5 \\
\hline CRUISE OLYMPIA & 164 & 3.0 & $3,439.0$ & $1,747.1$ \\
\hline CRUISE EUROPA & 192 & 3.0 & $4,026.1$ & $2,045.4$ \\
\hline OLYMPIC CHAMPION & 60 & 7.0 & 454.0 & 581.1 \\
\hline AURELIA & 120 & 12.0 & 488.4 & 325.6 \\
\hline ZADAR & 140 & 4.0 & 94.2 & 188.3 \\
\hline BRIDGE & 192 & 7.0 & $1,214.0$ & $1,387.4$ \\
\hline HELLENIC SPIRIT & 20 & 7.0 & 169.5 & 193.7 \\
\hline
\end{tabular}

Table 5: Second scenario: total emissions due to Ro-Ro/Ro-Pax ferries in Ancona harbour.

\begin{tabular}{|c|c|c|c|c|}
\hline $\begin{array}{c}\mathrm{NO}_{\mathrm{X}} \\
(\mathrm{Mg} / \text { year })\end{array}$ & $\begin{array}{c}\mathrm{CO} \\
(\mathrm{Mg} / \text { year })\end{array}$ & $\begin{array}{c}\text { COVNM } \\
(\mathrm{Mg} / \text { year })\end{array}$ & $\begin{array}{c}\mathrm{SO}_{\mathrm{X}} \\
(\mathrm{Mg} / \text { year })\end{array}$ & $\begin{array}{c}\mathrm{PM}_{10} \\
(\mathrm{Mg} / \text { year })\end{array}$ \\
\hline 1292.7 & 121.9 & 46.1 & 299.7 & 24.7 \\
\hline
\end{tabular}

\subsection{Third scenario}

In the third scenario the hotelling time and ship calls are the same of the second scenario whereas the manoeuvring time has been reduced to $0.5 \mathrm{~h}$ as suggested in another study on Ancona harbour [6]. This leads to a decrease in fuel consumed during manoeuvring phase (Table 6).

Table 7 shows that a reduction of $0.3 \mathrm{~h}$ of the manoeuvring phase leads to a decrease of more than $30 \%$ of $\mathrm{SO}_{\mathrm{x}}$ emissions compared to the second scenario while the remaining pollutants are almost unchanged.

The first scenario delivers a much higher estimate of the pollutants when compared to the other two scenarios (Fig. 1). In our opinion the second scenario is the most representative since it reflects the actual configuration of Ancona harbour in 2016 and follows more in deep the Entec's suggestions, between all to use a manoeuvring time of $0.8 \mathrm{~h}$ [14]. $\mathrm{NO}_{\mathrm{X}}$ is the main pollutant produced in all scenarios. A comparison was made between the values reported by Trozzi [15] for $\mathrm{NO}_{\mathrm{X}}$ emissions and the ratio of $\mathrm{NO}_{\mathrm{X}}$ to total ship calls, and the values from the three scenarios for the port of Ancona (Fig. 2). Being comparable, in terms of freight 
traffic, number of passengers and number of containers, Ancona port and Savona port show rather comparable values but Savona's values are higher. This is mainly due to the evidence that Savona shows a higher average amount of emissions per call (Fig. 3).

Table 6: Third scenario: ship calls and fuel consumption during hotelling and manoeuvring $(0.5 \mathrm{~h} /$ call $)$.

\begin{tabular}{|l|c|c|c|c|}
\hline Name of ship & Ship calls & $\begin{array}{c}\text { Hotelling } \\
(\mathrm{h})\end{array}$ & $\begin{array}{c}\text { Fuel consumption } \\
\text { (Mg/year) } \\
\text { hotelling }\end{array}$ & $\begin{array}{c}\text { Fuel consumption } \\
\text { (Mg/year) } \\
\text { manoeuvring }\end{array}$ \\
\hline SUPERFAST XI & 316 & 7.0 & $2,550.3$ & $1,821.68$ \\
\hline AF MARINA & 60 & 5.0 & 83.0 & 83.01 \\
\hline MARKO POLO & 144 & 26.0 & $1,350.2$ & 259.66 \\
\hline CRUISE OLYMPIA & 164 & 3.0 & $3,439.0$ & $1,091.97$ \\
\hline CRUISE EUROPA & 192 & 3.0 & $4,026.1$ & $1,278.40$ \\
\hline OLYMPIC CHAMPION & 60 & 7.0 & 454.0 & 363.18 \\
\hline AURELIA & 120 & 12.0 & 488.4 & 203.50 \\
\hline ZADAR & 140 & 4.0 & 94.2 & 117.70 \\
\hline BRIDGE & 192 & 7.0 & $1,214.0$ & 867.11 \\
\hline HELLENIC SPIRIT & 20 & 7.0 & 169.5 & 121.06 \\
\hline
\end{tabular}

Table 7: Third scenario: total emissions due to Ro-Ro/Ro-Pax ferries in Ancona harbour.

\begin{tabular}{|c|c|c|c|c|}
\hline $\begin{array}{c}\mathrm{NO}_{\mathrm{X}} \\
(\mathrm{Mg} / \text { year })\end{array}$ & $\begin{array}{c}\mathrm{CO} \\
(\mathrm{Mg} / \text { year })\end{array}$ & $\begin{array}{c}\text { COVNM } \\
(\mathrm{Mg} / \text { year })\end{array}$ & $\begin{array}{c}\mathrm{SO}_{\mathrm{X}} \\
(\mathrm{Mg} / \text { year })\end{array}$ & $\begin{array}{c}\mathrm{PM}_{10} \\
(\mathrm{Mg} / \text { year })\end{array}$ \\
\hline 1216.175 & 114.646 & 43.379 & 197.692 & 23.239 \\
\hline
\end{tabular}

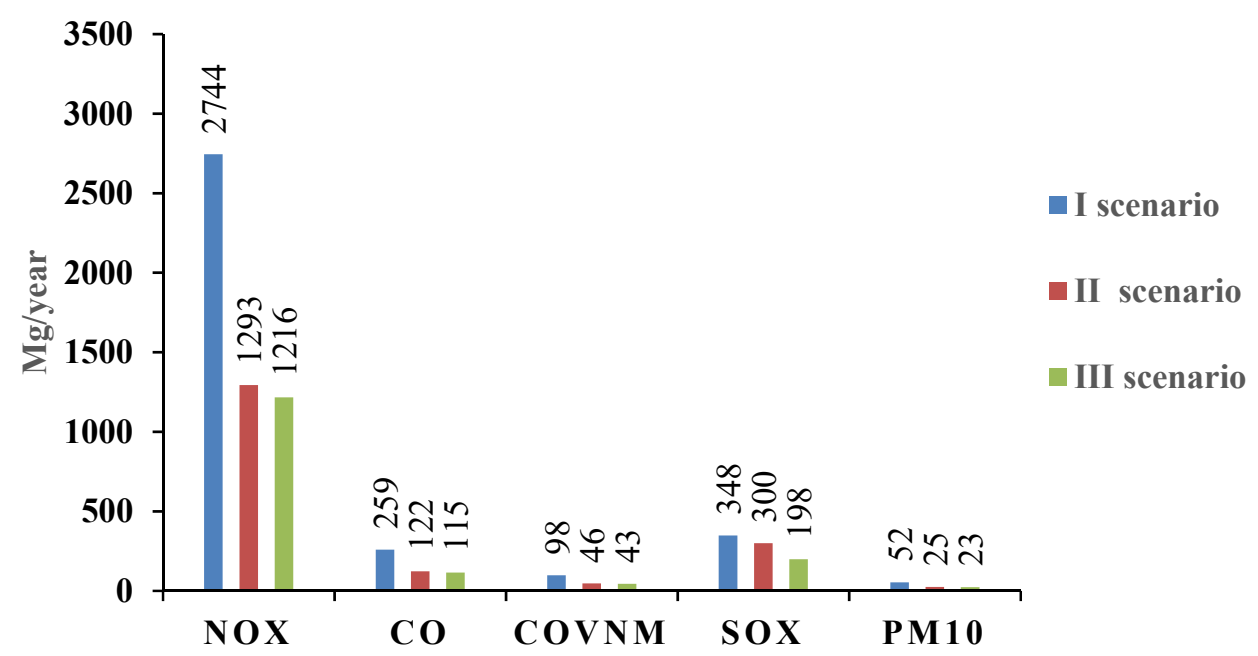

Figure 1: Total emissions due to Ro-Ro/Ro-Pax ferries in Ancona harbour in all scenarios. 


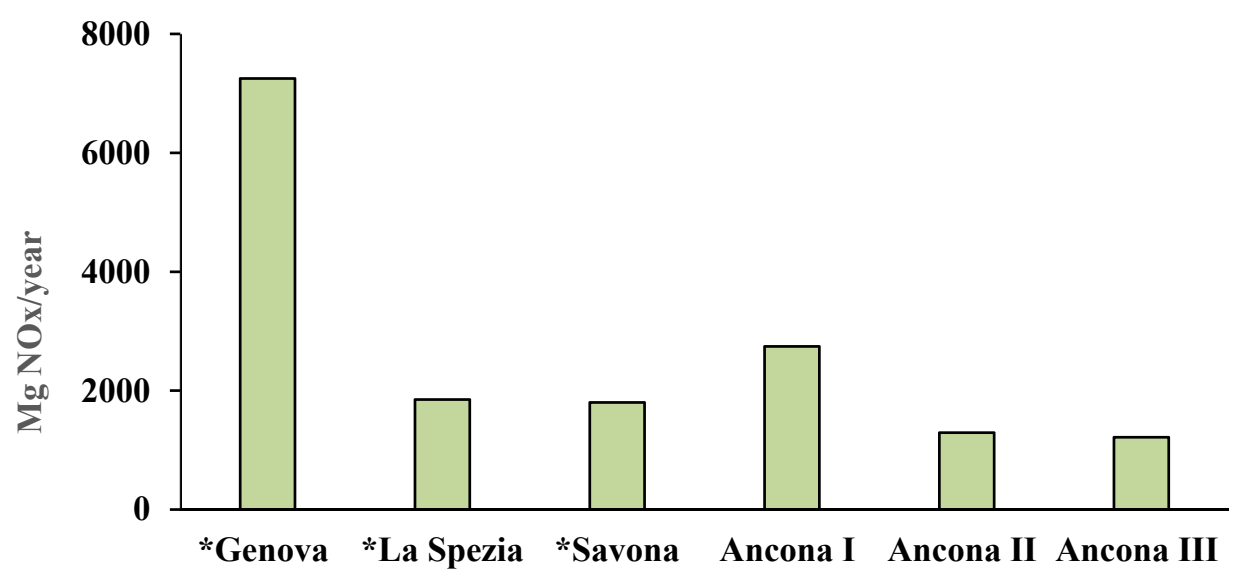

Figure 2: Comparison of $\mathrm{NO}_{\mathrm{X}}$ ship emissions for the three scenarios of Ancona port and selected other ports. (*Values reported by Trozzi [15].)

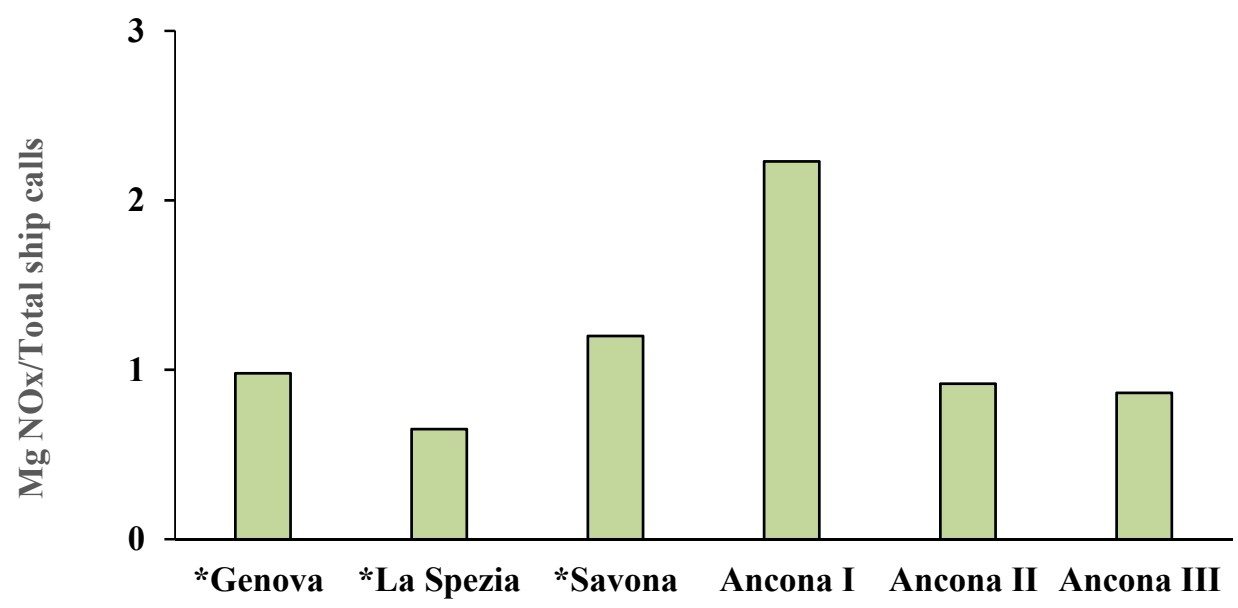

Figure 3: Comparison of average $\mathrm{NO}_{\mathrm{X}}$ ship emissions per call for the three scenarios of Ancona port and selected other ports. (*Values reported by Trozzi [15].)

\section{FISHING VESSELS}

Also for fishing vessels a Tier 1-like approach was applied due to the lack of detailed data on specific fuel consumption and engine power. For each boat, these are both very distinct based on fishing techniques and equipment on board. For this reason we decided to base the estimate on fuel consumption and apply the emission factors suggested by ANPA [16] considering the speed limit in Ancona port of 3 knots and, thus, an average fuel consumption of $24 \mathrm{l} / \mathrm{h}$ [17]. The estimate of the fuel consumption takes into account single manoeuvring phases of $1 \mathrm{~h} /$ day, an average activity of four days per week for each boat, and a total of 46 weeks of fishing and six weeks of fishing stop. 
In Table 9 we can see how, for the fishing boats, the very important airborne pollutants produced are $\mathrm{NO}_{\mathrm{X}}$, whereas the other pollutants considered have rather modest contributions. This is due to the cleaner fuel burned by fishing boats compared with the fuel employed by ferries and cruise ships. If we compare the second scenario of Ro-Ro/Ro-Pax, which we consider the most representative (it reflects the 2016 actual scenario for Ancona harbour and follows the Entec recommendation to use a manoeuvring time of $0.8 \mathrm{~h}$ ), we can observe that the emissions of fishing boats compared to those of the ships are in a range between $3 \%$ and $5 \%$ (Table 10). Only for $\mathrm{SO}_{\mathrm{X}}$ the rate is around $0.5 \%$, a value which is not in line with the other pollutants because of the different sulphur content of fuels. For ferries and cruise ships the emission factors were corrected based on the sulphur content of marine fuel which is much higher than that employed for fishgig boats.

Table 8: Summary of input parameters for fishing boats.

\begin{tabular}{|c|c|c|c|c|}
\hline $\begin{array}{c}\text { Number of } \\
\text { fishing boats }\end{array}$ & $\begin{array}{c}\text { Average fuel } \\
\text { consumption }(\mathrm{l} / \mathrm{h})\end{array}$ & $\begin{array}{c}\text { Manoeuvring } \\
\text { time (h/day) }\end{array}$ & $\begin{array}{c}\text { Fishing days } \\
\text { per year }\end{array}$ & $\begin{array}{c}\text { Total fuel consumed } \\
(\mathrm{Mg} / \text { year })\end{array}$ \\
\hline 182 & 24.6 & 1 & 184 & 700.2 \\
\hline
\end{tabular}

Table 9: Fishing boats total emissions.

\begin{tabular}{|c|c|c|c|c|}
\hline $\begin{array}{c}\mathrm{NO}_{\mathrm{x}} \\
(\mathrm{Mg} / \text { year })\end{array}$ & $\begin{array}{c}\mathrm{CO} \\
(\mathrm{Mg} / \text { year })\end{array}$ & $\begin{array}{c}\mathrm{COVNM} \\
(\mathrm{Mg} / \text { year })\end{array}$ & $\begin{array}{c}\mathrm{SO}_{\mathrm{x}} \\
(\mathrm{Mg} / \text { year })\end{array}$ & $\begin{array}{c}\mathrm{PM}_{10} \\
(\mathrm{Mg} / \text { year })\end{array}$ \\
\hline 41.31 & 5.6 & 1.68 & 1.4 & 1.05 \\
\hline
\end{tabular}

Table 10: Total emissions of fishing vessels, Ro-Ro/Ro-Pax ships, and the related ratio.

\begin{tabular}{|l|c|c|c|}
\hline Pollutant & $\begin{array}{c}\text { Total emissions } \\
\text { of fishing vessel } \\
\text { (Mg/year) }\end{array}$ & $\begin{array}{c}\text { Total emissions } \\
\text { of Ro-Ro-Pax } \\
\text { (Mg/year) }\end{array}$ & $\begin{array}{c}\text { Ratio between total emissions } \\
\text { fishing boats and total } \\
\text { emissions Ro-Ro-Pax (\%) }\end{array}$ \\
\hline $\mathrm{NO}$ & 41.31 & 1292.7 & 3.20 \\
\hline $\mathrm{CO}$ & 5.6 & 121.9 & 4.60 \\
\hline $\mathrm{COVNM}$ & 1.68 & 46.1 & 3.64 \\
\hline $\mathrm{SO}_{\mathrm{X}}$ & 1.4 & 299.7 & 0.47 \\
\hline $\mathrm{PM}_{10}$ & 1.05 & 24.7 & 4.25 \\
\hline
\end{tabular}

\section{MODELLING OF PM MIO $_{10}$ DISPERSION BY AERMOD}

The impact of the different port emission sources on the annual mean level of $\mathrm{PM}_{10}$ in Ancona was simulated by using the Gaussian plume model AERMOD (Environmental Protection Agency, USA). AERMOD includes an air dispersion modelling processor, a terrain-data preprocessor (AERMAP) and meteorological pre-processor (AERMET). Model pre- and postprocessing were performed using Lakes Environmental (Lakes Environmental Software, USA) user interface Version 9.7.0.

The $\mathrm{PM}_{10}$ emissions from Ro-Ro/Ro-Pax ships (scenario II) and fishing vessels were modelled as an area source located at the ground level.

Hourly meteorological data (i.e. wind speed and direction, temperature, atmospheric pressure, and cloud cover) from the Camerano meteorological station (13 $33^{\prime} 13.547^{\prime \prime}$; $43^{\circ} 31^{\prime} 8.198^{\prime} ; 120 \mathrm{~m}$ above sea level) were processed by AERMET. Terrain data were processed by AERMAP using GTOOPO30 digital elevation model with a horizontal grid spacing of 30 arc seconds (approximately $1 \mathrm{~km}$ ). 
Fig. 4 shows the annual average $\mathrm{PM}_{10}$ concentrations nearby the Ancona port for the year 2016. As we can see Ancona port is very close to the urban area so shipping and fishing activities strongly influence the local air quality. The annual average $\mathrm{PM}_{10}$ values obtained from the simulations (up to about $20 \mu \mathrm{g} / \mathrm{m}^{3}$ ) deserve further attention and monitoring. These are preliminary results and further data validations are necessary.

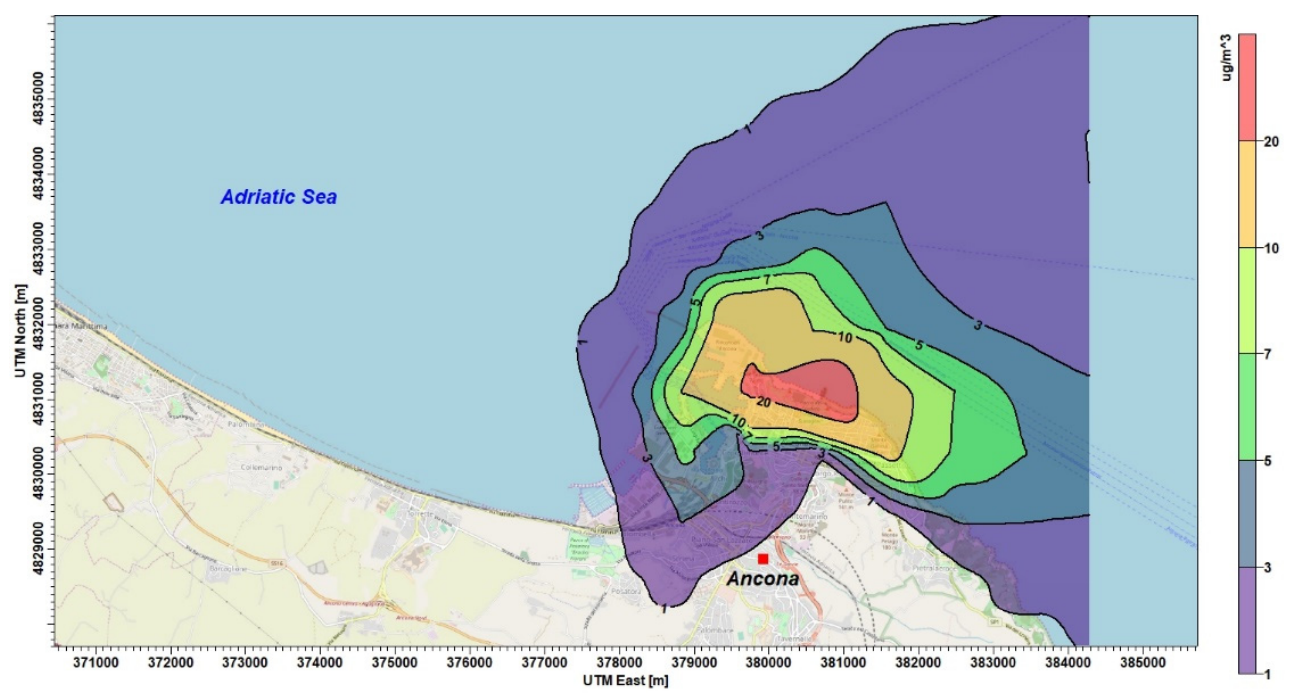

Figure 4: Annual average $\mathrm{PM}_{10}$ concentration modelled by AERMOD from Ro-Ro/RoPax and fishing vessel emissions.

\section{CONCLUSIONS}

The contribution of different port emission sources (i.e. Ro-ro/Ro-pax ships, and fishing vessels) to Ancona air pollution was evaluated. The levels of carbon monoxide, non-methane volatile organic compounds, nitrogen oxides $\left(\mathrm{NO}_{\mathrm{X}}\right)$, sulphur oxides $\left(\mathrm{SO}_{\mathrm{X}}\right)$, and particulate matter (PM) were estimated.

Three different emission scenarios from Ro-ro/Ro-pax ships were evaluated based on different annual ships calls, manoeuvring/hoteling schedules, and ship characteristics such as engine power. In the present study, a Tier 1 approach was applied for evaluating the emission from Ro-ro/Ro-pax ships given the lack of precise data about the operating conditions such as engine load, types of marine fuel and the sulphur content of the fuel consumed.

Most of the emissions in Ancona harbour are due to Ro-ro/Ro-pax maritime activities. The emissions from fishing vessels are up to two orders of magnitude lower than the emissions from Ro-ro/Ro-pax, thus almost negligible. $\mathrm{NO}_{\mathrm{X}}$ is the main pollutant produced in all scenarios, with values from $1,216 \mathrm{Mg}$ to $2,744 \mathrm{Mg}$ of $\mathrm{NO}_{\mathrm{x}}$ per year.

Changing the length of manoeuvring time from $0.8 \mathrm{~h}$ (first and second scenarios) to $0.5 \mathrm{~h}$ (third scenario) led to a reduction of $\mathrm{SO}_{\mathrm{X}}$ shipping emission up to $150 \mathrm{Mg} / \mathrm{year}$. This is because of the differences between the manoeuvring phase and hoteling phase, mainly the fuel Sulphur content $(0.1 \%$ or $1.5 \%)$ of marine fuel and the size of the engines (auxiliary engine or main engine).

Switching to 2016 ship scheduling (calls and hoteling times) produced a sharp decrease from $2,744 \mathrm{Mg}$ to $1,293 \mathrm{Mg}$ of $\mathrm{NO}_{\mathrm{X}}$ per year. 
The impact of the different port emission sources on the annual mean level of $\mathrm{PM}_{10}$ in Ancona was simulated by AERMOD. The annual average $\mathrm{PM}_{10}$ values are up to about $20 \mu \mathrm{g} / \mathrm{m}^{3}$ and deserve further attention and monitoring. For instance, a monitoring campaign should investigate the areas where the exposure of the local population to $\mathrm{PM}_{10}$ is of greatest concern.

Planning new scenarios for mitigating local air pollution requires data refinement and upper Tier approaches (Tier II or Tier III).

\section{REFERENCES}

[1] Donateo, A. et al., Contribution of harbour activities and ship traffic to $\mathrm{PM}_{2.5}$, particle number concentrations and PAHs in a port city of the Mediterranean Sea (Italy). Environmental Science and Pollution Research, 21(15), pp. 9415-9429, 2014.

DOI: $10.1007 / \mathrm{s} 11356-014-2849-0$.

[2] Contini, D. et al., The direct influence of ship traffic on atmospheric $\mathrm{PM}_{2.5}, \mathrm{PM}_{10}$ and PAH in Venice. Journal of Environmental Management, 92(9), pp. 2119-2129, 2011. DOI: 10.1016/j.jenvman.2011.01.016.

[3] European Sea Ports Organization (ESPO), ESPO Environmental Report 2018, EcoPortsinSights 2018.

www.espo.be/media/ESPO\%20Environmental\%20Report\%202018.pdf. Accessed on: 27 Aug. 2019.

[4] Bauleo, L. et al., Long-term exposure to air pollutants from multiple sources and mortality in an industrial area: A cohort study. Occup. Environ. Med., 76(1), pp. 4857, 2019. DOI: 10.1136/oemed-2018-105059.

[5] Murena, F., Mocerino, L., Quaranta, F. \& Toscano, D., Impact on air quality of cruise ship emissions in Naples, Italy. Atmospheric Environment, 187, pp. 70-83, 2018.

DOI: 10.1016/j.atmosenv.2018.05.056.

[6] Carletti, S., Latini, G. \& Passerini, G., Air pollution and port operations: A case study and strategies to clean up. WIT Transactions on Ecology and the Environment, vol. 155, WIT Press: Southampton and Boston, pp. 391-403, 2012.

[7] EU Directive 2005/33/EC, Directive of the European Parliament and of the Council of 6 July 2005 amending Directive 1999/32/EC, Official Journal of the European Union: Brussels, 2005.

[8] Merico, E. et al., Influence of in-port ships emissions to gaseous atmospheric pollutants and to particulate matter of different sizes in a Mediterranean harbour in Italy. Atmospheric Environment, 139, pp. 1-10, 2016.

DOI: 10.1016/j.atmosenv.2016.05.024.

[9] Gregoris, E. et al., Impact of maritime traffic on polycyclic aromatic hydrocarbons, metals and particulate matter in Venice air. Environmental Science and Pollution Research, 23(7), pp. 6951-6959, 2016. DOI: 10.1007/s11356-015-5811-x.

[10] EMEP/EEA, Air Pollutant Emission Inventory Guidebook 2016: Navigation (Shipping), 2016. www.eea.europa.eu/publications/emep-eea-guidebook-2016. Accessed on: 12 Sep. 2018.

[11] Dragović, B., Tzannatos, E., Tselentis, V., Meštrović, R. \& Škurić, M., Ship emissions and their externalities in cruise ports. Transportation Research Part D: Transport and Environment, 61, pp. 289-300, 2018. DOI: 10.1016/j.trd.2015.11.007.

[12] Rodríguez, G.D.M., Martin-Alcalde, E., Murcia-González, J.C. \& Saurí, S., Evaluating air emission inventories and indicators from cruise vessels at ports. WMU Journal of Maritime Affairs, 16(3), pp. 405-420, 2017. DOI: 10.1007/s13437-016-0122-8. 
[13] International Maritime Organization (IMO), Regulations for the prevention of air pollution from ships. Resolution MEPC, 176, p. 58, 2008.

[14] Entec UK Limited, Ship emissions inventory Mediterranean Sea, Final Report for Concawe, 2007.

[15] Trozzi, C., La valutazione delle emissioni di inquinanti atmosferici nelle aree portuali e le strategie di minimizzazione dell'impatto: esperienze nazionali e regionali. Presented at Verso una gestione sostenibile delle attività portuali, Ancona, Italy, 2019. www.arpa.marche.it/images/comunicazione/eventi/seminario_porti_2019/relazioni/0 1_trozzi_unece.pdf. Accessed on: 29 Aug. 2019.

[16] Bini, G. \& Magistro, S., Manuale dei fattori di emissione nazionali. Centro Tematico Nazionale Atmosfera Clima ed Emissioni Aria, Bozza Rapporto, n.1, pp. 1-193, 2002.

[17] Notti, E. \& Sala, A., Checkup energetici a bordo di imbarcazioni per la pesca commerciale.

www.an.camcom.gov.it/sites/default/files/galleria/RF_CHECKUP_CAMCOM_AN_ 2012_finale.pdf. Accessed on: 29 Sep. 2018. 